\title{
A Possible Pragmatic Aim of Belief
}

\author{
Un posible objeto pragmático de la creencia \\ MARCO ANTONIO JOVEN ROMERO \\ UNED - Universidad Nacional de Educación a Distancia
}

Recibido: 12/12/16 Aceptado: 27/12/16

\begin{abstract}
RESUMEN
Los vínculos entre creencia, verdad y pragmatismo son recurrentes en epistemología. Recientemente, algunas publicaciones han analizado los objetivos de la creencia, siguiendo la popular frase de Williams 'la creencia aspira a la verdad'. Algunos autores defienden un vínculo normativo entre creencia y verdad y exploran las posibles normas epistémicas de la creencia, mientras que otros prefieren hablar de valores. Otros filósofos defienden que la creencia no siempre aspira a la verdad. Aquí analizo y comparo estas ideas sobre creencia, verdad y pragmatismo, defendiendo que la creencia se puede entender mejor desde una relación constitutiva entre creencia y verdad.

PALABRAS CLAVE
\end{abstract}

CREENCIA, VERDAD, PRAGMATISMO, ACEPTACIÓN, WISHFUL THINKING.

\begin{abstract}
The links between belief, truth and pragmatism are recurrent topics in epistemology. Recently, some publications have analyzed the aims of belief, following Williams' popular statement 'belief aims at truth'. Some of these authors defend a normative link between belief and truth and they explore the possible epistemic norms of belief, while others prefer to analyze beliefs in terms of values. Other philosophers defend that beliefs do not always aim at truth. Here I analyze and compare these ideas about belief, truth and pragmatism defending that belief can be better understood with a constitutive relationship between belief and truth. KEYWORDS
\end{abstract}

BELIEF, TRUTH, PRAGMATISM, ACCEPTANCE, WISHFUL THINKING. 


\section{INTRODUCTION}

IN THE LAST YEARS, some philosophers analyze the link between belief and truth, finding a start point in Williams' popular statement'belief aims at truth'.

The teleological approaches state that belief aims at truth in a constitutive way: if a state or propositional attitude does not aim at truth, then it is not a belief. The standard of correctness of a belief is. We can interpret the teleological approach from the agent goals, so in terms of truth: belief aims at truth because the agent has formed the belief in order to be a true belief. We also can interpret the teleological approach in terms of the mechanism of belief formation, that is, in terms of belief itself: belief aims at truth because the agent develops -by evolution or training- mechanisms to form true beliefs.

The normative approaches state that the agent must accept a norm that judges a belief in terms of a truth value. The standard of belief correctness is . There are different options about the formulation of this norm.

Both teleologists and normativists agree that there is a constitutive link between belief and truth, but they disagree on the nature of this link. The normativist asks the teleologist for the nature of the truth regulation mechanism of belief -if an agent believes, she considers to be true-, as they think in an intrinsic norm. But a strong norm of truth makes it difficult to explain why beliefs do not always reflects truth. So the norm is likely to focus on the nature of the aiming process -belief aims at truth-, and not on the results of beliefs -that is, how well the belief reflects reality or truth. The teleologist would ask what differences it makes to consider better than. The norm may be explained in terms of some kind of metaphysical motivational internalism and the teleologists usually reply analyzing the aiming process in terms of evolution and training. If the agent develops a belief not aiming at truth, normativists would say that she has violated the norm due to an irrational behavior, while teleologists would say that evolution and training mechanisms have not worked as they are supposed to do. Finally, normativism relies on rationality while teleologism do not.

Contrary to these options, other philosophers do not support the privileged status of truth, refusing the constitutive link between belief and truth. Truth is not the only criteria for belief, and, in the most radical cases, truth does not exist or it is reducible to other considerations. That opens some new options like or . Other authors defend a constitutive link between belief and truth, but they also relate truth and pragmatic considerations: what is truth, is practical.

In this paper I firstly discuss the analysis of some contemporary authors about belief, truth and pragmatism. Sometimes such analyses are directly related to pragmatism, other times they involve ideas that can be considered from a pragmatic point of view, although they do not properly mention it. Then, I take and apply the ideas some pragmatist philosophers about truth established 
during the last third of the $20^{\text {th }}$ century and the beginning of the $21^{\text {th }}$ century. I expose how this ideas may contribute to face some of the problems typically presented and I state that a constitutive link between belief and truth is mandatory to explain the nature of these concepts.

\section{BELIEF AND PRACTICAL ISSUES}

In this section I discuss the ideas about pragmatism and belief -to a lesser extent also truth- of some contemporary authors: Papineau (2013), Owens (2013), Engel (2013a, 2013b), Whiting (2010, 2013a, 2013b, 2014), McHugh (McHugh \& Unwin 2015) and Unwin (2007). Some of them stand for a normative position -Owens, Engel, Whiting and McHugh- while others are more attached to a pragmatic one -Papineau and Unwin. Anyway, they tend to consider a constitutive role in belief aiming at truth. Sometimes I also quote ideas from Haack (1996), Hookway (2004), Kitcher (2002) and Misak (1998, 2004).

David Papineau (2013) defends a teleological position about belief and truth. There is not any norm about and epistemic evaluations are not always valuable (Papineau 2013, p. 69). Furthermore truth is not always valuable from a non-epistemic perspective -i.e. from personal, moral or aesthetic perspectives (Papineau 2013, p. 68). He focuses the problem not on the statement or on the nature of belief, but rather on the nature of truth, not always being something valuable. By contrast, Papineau defines belief in terms of biological design (Papineau 2013, p. 79), and more specifically, he states that beliefs help to achieve and satisfy desires generally fitting the way the world is (Papineau 2013, p. 73).

Some normativists would reply that the doxastic norm about belief is not applied on final results -belief reflecting reality vs belief failing to reflect reality- but just on the nature of the aiming process: no matter if our beliefs finally reflects reality, but the agent will when believing is to reflect reality and that is the norm (note Papineau's (2013) words «even if we can’t [ignore evidence]» (p. 79).

Other normativists would say that getting truth is a pragmatic consideration that drives the agent to her satisfaction (Owens 2013, pp. 37, 42). Nevertheless, Owens (2013) does it from a normative point of view: belief points at truth and as a result we get successful agency. If truth and successful agency are confronted, the normative account prevails: belief should aim at truth.

In a similar vein, Daniel Whiting (2010, 2013a, 2013b) defends a normative account of belief aiming at truth in a fallibilist way: he supports that and . Whiting thinks that the truly normative nature of belief is constitutive and not evaluative. In an analogy with the chess game, we have some previously permissible movements for each piece, so we move the pieces following these rules and we do the opposite (Whiting 2010, 2013b). Obviously, that is not the only necessary thing in order to win a game of chess: we use good movements. But that is an evaluative question that does not define chess. In a more general 
sense, truth is constitutive of belief and practical outcomes do not define belief but just contribute to evaluate it.

In this fallibilist proposal, Whiting suggests that the subject aims to believe the truth as a consequence of some kind of previous acceptance of truth. He admits that sometimes the norm of truth may be not enough to explain final beliefs, but other non-epistemic or non-alethic considerations are needed, like the practical ones (Whiting 2013a, p. 194; 2013b, p. 131). So far, belief should not aim at falsity and practical considerations are especially important when acting.

Recently, Whiting has deeper into the dichotomy between knowledge and practical considerations when forming beliefs (Whiting 2014, p. 2, 6), and he defends that correct -true- beliefs are caused by evidences and in that way they promote or enable conditions for practical actionsHe also states that focusing in practical actions and reasons explain agents' commitment to evidentialism better than focusing only in truth (Whiting 2014, pp. 8-9; McHugh \& Whiting 2015 , p. 5). Whiting considers that truth and practical things are not at odds, but related. Sometimes, he argues that believing practical reasons implies believing at truth, because generally what is practical is true (Whiting 2014, p. 9).

However, in some examples beliefs aim at truth and not necessarily at practical reasons. Imagine that believing something false would reward you -imagine that believing today is not Sunday would allow you to win 1.000\$: if only practical reasons mattered you would belief that today is not Sunday but you cannot. In fact, it may be argued that the practical is not true there and that belief aims directly at truth, contradicting that aiming to believe practical reasons generates aiming to believe what is true. Although it can be argued that truth is practical even in these cases (Whiting 2014, p. 18) -e.g. you realize you do not have to work-, the most practical outcome is likely to be the result of believing today is not Sunday. McHugh and Whiting (2015) also consider that in cases of wishful thinking what would benefit you influences your beliefs, but this cannot be treat as a reason for belief (McHugh \& Whiting 2015, p. 6): the only reason is evidence.

Then, Whiting states that truth motivates successful agency, effective actions. More specifically, belief aims at truth -better said, belief may aim at truth and belief should not aim at falsity- and truth usually generates practical outcomes, so belief aims at practical outcomes (Whiting 2014, pp. 21-22).

In general, it seems that Whiting is identifying truth with practical things in a rationalistic manner. Sometimes while writing it seems so (Whiting 2014, p. 19). Nevertheless, I would not identify both concepts. Imagine a terminally ill person whose child is a hated terrorist, but she does not believe that: it would not be practical, successful or effective for that person to get the truth or knowledge. In the example of getting $1000 \$$ for believing falsely, the truth is not practical. 
Owens is also interested in the pragmatic account of belief and truth (Owens 2013, pp. 42-43) in which the source of any normative account is the capacity of producing valuable -and I would say practical- states, and ultimately emotional fitness. Nevertheless, Owens opens the possibility of truth not implying successful agency, like in the example of the terminally ill person whose child is a hated terrorist. That would mean that this pragmatist view could not always stands for both truth and practical aims. Owens (2013) explores a more general definition of : «To be entitled to believe thatis to be entitled to useas a default assumption in one's practical reasoning»(Owens 2013, p. 45).

Nevertheless, we face here other problems: beliefs are transparent, involuntary and context independent while assumptions are not. Belief is transparent, so when believing the agent only take herself moved by considerations relevant to the truth of the belief: we cannot knowingly and deliberately belief the falsity; if the agent ask herself whether to belief that, she is asking herself whether . This step is explained by teleologists in terms of, while normativists use . Acceptances, assertions and assumptions can incorporate other considerations, like pragmatic ones. Belief is formed automatically -if we belief, then we directly and automatically consider to be true- while acceptances, assertions and assumptions are not. So the agent can deliberately accept, assert or assume something false while she cannot deliberately believe something false. Just to give a -popular- example, a lawyer may belief her client to be guilty -involuntary and not depending on the context- but she may accept and assume her client's innocence during the trial (Unwin 2007, p. 109; Whiting, 2013a). The difference is important because it allows many authors to think of belief aiming at truth and of assertion aiming at pragmatic considerations. It also means that our actions are not always motivated by beliefs but also by acceptances in a pragmatic manner. Pragmatism might be considered «[t]he thesis that we should replace our beliefs, as traditionally understood, by what we call acceptances» (Unwin 2007, p. 163), because «[w] hat is relevant is the deliberate adoption of a goal» (Unwin 2007, p. 175).

For these reasons Owens is doubtful about default pragmatism on beliefs and supports his former definition (Owens 2013, p. 50). While facing cases like the terminally ill person with a hated terrorist child (Owens 2013, p. 51), Owens refers to a normative nature of knowledge (Owens 2013, p. 52). These epistemic norms work as conventions.

In a similar vein Kitcher (2002), Hookway (2004) and Misak (1998, 2004) supply some interesting ideas from their analysis of Peirce: reality is external and mind-independent, while truth is an abstract reflection whose ideal limit is reality. We may say we develop our truth in terms of pragmatic considerations. There might be reality without truth and there might be truth -even common social truth- without reality. Among the former, discoveries that have not been 
done yet. Among the latter, social settled truths that came to be false, like the Earth being the center of the universe. We never know when inquiry and belief have been developed far enough: settled belief taken to be true and not reality is the best inquiry can obtain. Beliefs must be settled in terms of evidence and community verdicts, and not because of their inner consistency, coherence or personal and social wills. All this implies a fallibilist position about beliefs and truth based on rigorous inquiry, and finally on evidence, perception, experience and public commitment, paying special attention on scientific methods (Misak 1998, p. 410). For Misak, the Peircean account of belief and truth implies some kind of normativity. But this normativity is not related with beliefs corresponding to reality, but just to a commitment to correct inquiry based on evidence, experience, perception and community verdicts (Misak 2004, p. 65).

The Peircean account of our problem supposes an attempt to accommodate realism and pragmatism: Beliefs -based on inquiry- aims at truth in terms of success and use, developing settled beliefs. These settled beliefs aims to be real. So this pragmatism implies a realism, as it admits an external reality as the last step of the aiming process.

Engel (2013a, 2013b) defends doxastic absolutism and a normative account of belief against doxastic relativism (Engel 2013a, pp. 23-24, 28; 2013b, p. 51). Susan Haack (1996) supports a similar position. Engel also relates teleological accounts with hypothetical instrumental values and a variety of goals when believing, and as a result he identifies these accounts with relativism (Engel 2013b, p. 37). He (2013a) seems to explain cases of wishful thinking like that of the terminally ill person pointing that they are not proper beliefs because agents do not investigate and take evidences (Engel 2013a, p. 29). In a similar manner, Susan Haack calls pseudobeliefs these cases of «of obstinate loyalty to a proposition that one half suspects is false, and of sentimental attachment to a proposition to which one has given no thought at all» (Haack 1996, $\square 4$ ). This seems to point to a redefinition of belief that cannot apply to many popular and philosophical cases in which we use the word. If we do not investigate further or we do not do it fairly, the state cannot be considered a belief. Nevertheless, Engel gives a more accurate description and solution of the problem:

Now what about the troublesome cases where we do not deliberate explicitly and consciously about whether to believe that , such as wishful thinking, self-deception, and other kinds of irrational beliefs? (...) Even though these people obviously do not reason consciously with and from their beliefs in accordance with norms of evidence, it is less clear that they have no understanding at all of what a proper belief should be (...) So it is not clear that the norm of truth does not in such cases regulate thinking tacitly (Engel 2013b, p. 56). 
Even if the wishful thinker has a false belief, she believes that such false belief aims at truth. The wishful thinker is subject to the constitutive norm or value of belief, her belief continues aiming at truth as far as she attends to -incorrect- evidences. In a similar vein, Unwin establishes that truth, as an aim of belief, may be valuable to some extent, but «[i]t is not at all clear just how much importance should be assigned to truth-seeking» (Unwin 2007, p. 184), as we can see in wishful thinking examples. However, truth has a central role in the belief-desire web and it ensures that pragmatic considerations do not drive us to a hard relativism or often to wishful thinking situations (Unwin 2007, p. 184).

Unwin's idea could be stated in this way: belief aims at truth. There is a practical biological desire for truth, but truth value or norm is not so strong for establishing that belief aims at truth. Sometimes we develop beliefs attending to other desires. That offers an interesting analysis of wishful thinking cases. Another different analysis of these ideas would be that belief aims at truth and belief reflects truth. The difference here would be that there is a constitutive value or norm of belief pointing at truth -belief aims at truth- but belief not always satisfies such aim. So, the wishful thinker would aim at truth, but the truth she considers is not the -epistemic or socially accepted- truth: she fails in believing the truth. This option is the same as the defended by Engel, and this is what I am defending here.

\section{DAVIDSON, RORTY, BELIEF AND TRUTH}

In this section I will examine Davidson's and Rorty's ideas about truth and belief. It should be noted that here I skip the previous theoretical schemata: belief aiming at truth and its normative or teleological nature. I introduce Davidson's concept of belief and I analyze Davidson's truth, in order to apply all this theoretical development to the problems of belief aiming at truth. Then I explain Rorty's view of truth and I relate both authors. Finally I show the conclusions in terms of the theoretical schemata I am following.

In words of Davidson (194), «[b]elief is built to take up the slack between sentences held true by individuals and sentences true (or false) by public standards» (p. 321). It is an irreducible concept -it cannot be define in terms of other concepts- that the agent use in order to develop consistent and coherent theories. If it were reducible, it would not be so a central concept and there would be no necessity of using it (Davidson 2000, p. 17). This gives us an idea of Davidson thoughts about belief as a non-dispensable concept to mediate between the agential and the social.

Interestingly, although they are concepts like belief are and they are embedded into a network (Davidson 1974, p. 311). The point when treating belief, truth, and other concepts like desire, acceptance, knowledge, action or cause is to relate all of them, and not trying to define them in terms of clearer, simpler 
or more fundamental concepts -e.g. truth cannot be understood as warranted assertability (Davidson 2000, p. 8).

Contrary to concepts, evidence is external and it supplies a point for interpretation. The evidential base for the concepts creation consists of facts whose interpretation depends on the context (Davidson 1974, p. 320). Once all the possible evidence is in, alternative theories about it remain open. Truth has no application or interest if it has no empirical connection, and the connection problem between both is inseparable from the connection problem between contents and attitudes (Davidson 1996, pp. 277-78).

Truth is not an object but a concept. This view of truth allows us to establish that different irreconcilable beliefs may be considered true. That is because we have no appropriate entities available for explaining why true sentences are true and the false ones are false: truth is irreducible. The closest concept is evidence, but it is not enough, as its treatment is social and subjective: evidence has no unique interpretation. The best we can do is to keep on inquiring (Davidson 2000, p. 6). Pragmatists usually consider that, as far as we cannot reach truth, true beliefs are the best researched and most successful beliefs. Davidson's point is that truth as an irreducible concept is important because it allows us to understand sentences and to be thinking creatures.

In short, for Davidson truth is irreducible, it cannot be defined in terms of warranted assertability, most successful applications or something like that. Moreover, truth is not independent of other attitudes -e.g. desires. Although the best an agent can do is to research from evidences to form beliefs aiming at truth, these beliefs are always fallible. Furthermore, beliefs are built by the thinking creatures to link sentences considered true by agents and sentences considered true by communities (Davidson 1974, p. 321).

The interpretation we can do of the doxastic aim of belief from Davidson's ideas is ambiguous. We can consider that belief aims at truth in a normative way and as these concepts are dependent and related -but irreducible-, we could explain phenomena like wishful thinking considering that desires also come into play. Nevertheless, as the agents cannot get the unerring truth but they just inquire from evidences, and as beliefs help to take up the slack between agent's truth and community's truth -something that can be done in very different ways-, a teleological account based on flexible hypothetical values and on this deflated truth -the only the agent can obtain- seems to be suitable.

Similarly to Davidson, Rorty focuses specially in the analysis of truth. Although it cannot be said that Rorty faces the problem I am dealing with -the aimf of belief-, his treatment of truth is useful to my analysis and can be broadly put in the same line of thinking of Papineau and Unwin as I will show at the end of the section. 
Rorty, when analyzing Davidson, considers that his irreducibility defense of concepts like truth and belief is caused by a cautionary use of these terms (Rorty 2000b, p. 77). For Rorty, truth is reducible to use and practice, and so there is nothing much to say about truth itself. Generally speaking, Rorty rejects the authoritarianism of concepts like god, sin, truth, and finally reality. He also refuses Habermas and Apel goal of universal validity of belief and truth based on a commitment to justification to everybody in every community in terms of reality.

Rorty is against the idea of two different norms about believing, warranted assertability and truth (Rorty 1998, p. 27), which is very useful to interpret some false beliefs, like wishful thinking examples I have previously mentioned. Actually the difference is «a goal for metaphisically active inquirers», while Rorty defines himself and Davidson as metaphysical quietists (Rorty 1998, pp. 29,38 ). What Rorty proposes is a concept of truth based on aptness and usefulness, and that concept would not need of any realism nor metaphysical extra element. The pragmatist may state that, although there may be many goals, none of them is metaphysically foundational. What the agent wants when believing is to justify her belief as to as large and as many audiences as possible. The difference between justification -as a pragmatic concept- and truth is that the former does not call for metaphysical presuppositions while the latter usually does in Philosophy (Rorty 2000a,p. 2). We cannot think of neutral fundamental principles and concepts, like truth traditionally understood. This difference may be caused by an over-attentions to fact-stating. Achievement of justification is only temporary.

The relationship between truth and justification implies that the word truth usually has a cautionary use. The difference allows us to treat justified false beliefs (Rorty 2000a, p. 4). The ability to believe implies the ability to argue about what to believe. For Rorty, all we have about beliefs and truth are competent audiences, and what we want is to justify and extend our beliefs to more and bigger audiences, although we cannot get the whole community. Objectivity would not be different to extended intersubjectivity. A social practice can be transcended only by another social practice, and not by fundamental concepts like philosophical truth. Beliefs and desires are into a social network -personal coherence, truth and community go together-, but that does not imply fundamentalism or universality (Rorty 2000a, p. 16). Different communities may have different networks of beliefs, desires and truths, being all of them coherent. The only thing in common along every person and community we may sketch is just curiosity, the desire of inquiry. But this does not suppose the agent under some normative nature that enforces her beliefs to aim to aim at truth, but he just thinks that beliefs aim at aptness and usefulness into their social and natural contexts. In Rorty's (2000a) words: 
what about the claim that all human beings desire truth? (...) [t]he claim that all of them desire to justify their beliefs to some, though not necessarily all, other human beings, and the claim that they all want their beliefs to be true. The first claim is unobjectionable, and the second dubious (p. 4).

So Rorty explains belief in terms of use, usefulness and justification. To make a difference of beliefs that aim at truth and beliefs that aim at something merely is the position of realists, and Rorty finds no explanation for it. At the same time, it seems that Rorty defines justification in terms of usefulness into the range of use possibilities (Rorty 1998, p. 19, 32).

We can state that in Rorty's terms . That is similar to Papineau's thinking: «[i]t is not always of personal, moral, or aesthetic value to avoid false belief (...) I therefore accept that there are cases where there is nothing at all wrong with believing falsely» (Papineau 2013, p. 68). Nevertheless, in his quotes, Papineau assume an external truth that judges beliefs, something that Rorty does not. Note that this is different to the idea Owens and Whiting sometimes seem to defend: if it is true, it is good. Unwin (2007) also defends some kind of pragmatism about belief and truth but at the same time he establishes that a common desire for epistemic truth puts the agents away from radical relativism and prevents the agents from falling continuously in wishful thinking cases.

IV. CONCLUSIONS: DILEMMAS AND KEY POINTS WHEN ASKING WHY WE BELIEVE.

I have showed different ways of fitting truth, belief and practical issues. These different accounts when fitting belief, truth and pragmatic considerations show some problems, dilemmas and also some key insights. And we can consider two main different positions: belief aims at truth -considered as reality or epistemic knowledge- and belief aims at pragmatic considerations. It should be noted that depending on the authors these statements mean different things -e.g. sometimes the same sentences apply to normative and teleological accounts. Furthermore, other authors (Owens, Whiting, McHugh) try to demonstrate that epistemic and pragmatic views are not at odds, establishing that the epistemic goal implies the pragmatic goal.

If we consider belief aiming at truth, we can find some counterexamples, like wishful thinking ones: I may belief the girl I am in love she does love me, although the opposite evidence. I may belief Chicago Bulls will win the NBA league, although the evidence shows that is Boston Celtics that are going to win. The mother whose son is a hated terrorist believes he is not, in spite of the evidence. In these cases belief does not mirror truth and we can analyze them from two different views. If we accept a constitutive relationship between belief and truth, we can say that they fail in their goal: all beliefs emerge under a norm of aiming at truth and sometimes they simply cannot get their 
goal, although that goal of truth is always there. There is a constitutive norm on belief aiming at truth, something that follows on very well from realist and rationalistic accounts and from a defense of metaphysical content of belief and truth. On the other hand, for teleologists like Papineau this constitutive norm can also be analyzed from a biological position, deflating its normativity. We can also argue that wishful thinking beliefs are beliefs that aim at truth on the basis of false and poor evidence, but evidence: I see the girl touching her hair the last time I met her, I remember NBA statistics of 1961, the mother remember his son helping a homeless when he was 5 . That would support the constitutive link between belief and truth.

If we do not accept this constitutive relationship, we can state that belief does not have to aim at truth and we can in turn say that they just aim at pragmatic considerations -e.g. beliefs aim at justification. So when I believe the girl loves me, Chicago Bulls are going to win the NBA or when the mother believes his son to be innocent, we do that in order to get some emotional fitness: it is the most practical thing. Nevertheless, this view faces other counterexamples. If we were to win $1000 \$$ for believing today is not Sunday and if belief aims to practical things, as far as getting $1000 \$$ is practical, we should believe today is not Sunday. But belief is transparent and we cannot decide beliefs automatically at will. We can accept that today is not Sunday in order to get the prize but -voluntary, context-dependent and not transparent- is not belief. As a result, many authors have related pragmatism with acceptances: we have to change our beliefs into well though practical acceptances (Unwin 2007; Whithing 2013a). In this sense transparency and context-independency of belief are good arguments for the constitutive nature of belief aiming at truth.

Interestingly, a temporal argument can be stated for the belief aiming at truth account (Haack 1996, $\square 10$; Unwin 2007, p. 147). Although sometimes it is more useful not to believe the truth in the short-run and we act in this manner, like in wishful thinking, in the long-run it is more practical and better for our emotional fitness to know the truth: the sooner I realize the girl does not love me, the softer my disappointment and the sooner I will go on with my life without paying attention on that girl. The sooner I realize Chicago Bulls will not win the NBA League, the softer my disillusionment. It may be argued that in examples like the terminally ill mother whose child is a hated terrorist it is always better for her to believe the falsity, as it is the most practical. The normativist could reply that in these extreme cases we are playing with no temporal dimension as the agent is going to pass away soon. This temporal argument adjusts well to the reconciliation between the epistemic and the pragmatic perspectives some authors are promoting (Owens, Whiting, McHugh). In their terms, what is true is practical, so the epistemic perspective is included into the pragmatic one. If we show counterexamples in which what is true is not practical -e.g. wining 
$1000 \$$ for believing today is not Sunday- they may say that in the long-run believing the truth will prevent us of many problems -e.g. going to work when we must not, taking care of our children as they are not at school. But as I see it, a pragmatist choice would take $1000 \$$ as the results of believing truly are hypothetical and less practical.

We also may say that there is a normative account of belief, not based on true but on practical things: belief should aim at practical things. Nevertheless, this account would not resist counterexamples as the previously mentioned. The authors who state that belief aims at pragmatic considerations do not consider the statement under a norm but they explain their view in terms of evolution and biological design (Papineau 2013; Rorty 1998).

Another problem -related with that of acceptances and transparency of belief- for the belief aiming at pragmatic considerations account is that in some contexts it is useful to adopt some beliefs while in other contexts the useful thing is to adopt the contrary beliefs: a christian evolutionary biologist would believe in evolution when working and she would believe in Genesis when being at church on Sunday. Authors who refuse normative accounts and realism like Rorty would say that «[a]11 religious pragmatists need to do is to be reasonable, to keep their religion out of their scientific and political activities (...) reconciliation would only be necessary if belief in both led to some form of social awkwardness» (Rorty 1996). Nevertheless, belief is transparent and individually context-independent (Unwin 2007). It is important to note that belief being individually context-independent does not imply it to be socially contextindependent. That is, beliefs change from community to community in their contexts -e.g. the community of evolutionary biologists and the community of catholics- but beliefs do not change for an agent in her different contexts -e.g. the lawyer who believes her client to be guilty no matter the context, although she accepts her innocence during the trial- unless the new contexts supply stronger evidence. The fact that different personal contexts may supply new stronger evidences should not be confused with belief being context-independent.

In short, both positions apparently present counterexamples: on the one hand, the epistemic account account may be contrasted with the wishful thinking examples where belief does not reflect truth, knowledge or reality. Nevertheless, it can be replied that the constitutive nature of belief aiming at truth is based of an internal motivational disposition that pushes the agent to reflect the world as it is. Mistakes like wishful thinking examples are due to poor or no evidence -maybe infected by a conative feature- but even in these beliefs, there is a truth aim. On the other hand, belief aiming just at practical things faces the problem that beliefs cannot be automatically developed at will, so not always can we believe the practical -e.g. we cannot believe today is not Sunday to win $1000 \$$. 
A third option to the debate would be to relate the epistemic and the pragmatic perspectives, stating that what is true is practical (Owens, Whiting, McHugh) -i.e. belief aims at truth, truth is practical so belief aims at pragmatic considerations. But what is true is not always practical and what is practical is not always true: for the terminally ill mother whose child is a hated terrorist is not practical to believe the truth. It is practical for me to believe that today is not Sunday in order to win $1000 \$$. Some philosophers may tell that generally speaking and in the long run it is more useful to know the truth: today is Sunday, so I do not have to go to work and I have to take care of my children as they are not at school. But I would say that when forming beliefs, the pragmatic force of earning $1000 \$$ is much stronger than the hypothetical problems derived of having the false belief of not being Sunday. We cannot say that truth is practical in these cases.

A much more suitable way to incorporate pragmatism to our analysis would be that we should replace our beliefs by acceptances, changing them depending on the contexts in order to get the most practical outcome. But acceptances are not proper beliefs, as far as they are not transparent, automatic and contextindependent.

\section{REFERENCES}

BRANDOM, R. (Ed.) 2000:Malden, Mass: Blackwell Publishers.

CHAN, T. (Ed.) 2013: Oxford: Oxford University Press.

DAVIDSON, D. 1974: «Belief and the Basis of Meaning», Synthese, 27(3-4) (1974), pp. 309-323.

_- - «The Structure and Content of Truth», The Journal of Philosophy, 87 (6) (1990), pp. 279-328.

- - - «The Folly of Trying to Define Truth», The Journal of Philosophy, 93 (6) (1996), pp. 263-278.

- - - «Truth Rehabilitated», Truth, Language and History. Oxford: Clarendon Press, 2000, pp. 3-18.

ENGEL, P., «Belief and the Right Kind of Reason», (3) (2013a), pp. 19-34.

- - - «In Defense of Normativism About the Aim of Belief», en T. Chan (ed.),The Aim of Belief. Oxford: Oxford University Press, 2013b, pp. 43-85.

HAACK, S. «Concern for Truth: what it Means, why it Matters», Annals of the New York Academy of Sciences, 775(1) (1996), pp. 57-63.

HOOKWAY, C., «Truth, Reality, and Convergence». Cambridge: The Cambridge Companion to Peirce, 2004, pp. 127-149. 
KITCHER, P., «On the Explanatory Role of Correspondence Truth», Philosophy and Phenomenological Research, 64(2) (2002), pp. 346-364.

McHUGH, C. \& WHITING, D., «Recent Work on the Normativity of Belief». Analysis Reviews(2015).

MISAK, C. J., «Deflating Truth: Pragmatism vs. Minimalism» The Monist (1998), pp. 407-425.

- - , 2004: Oxford: Oxford Philosophical Monographs.

OWENS, D., «Value and Epistemic Normativity», Teorema: Revista internacional de filosofía, 32(3) (2013), pp. 35-58.

PAPINEAU, D., «There Are No Norms of Belief», en T. Chan,The Aim of BeliefOxford: Oxford University Press, 2013, pp. 64-79.

RORTY, R. 1991: (Vol. 1). Cambridge: Cambridge University Press.

_- —, «Something to Steer By» [Review of the book by A. Ryan], (12) (1996).

- - , 1998: (Vol. 3). Cambridge: Cambridge University Press.

- - - «Universality and Truth», en R. Brandom Malden, Mass: Blackwell Publishers, 2000a, pp. 1-30.

- - - «Response to Donald Davidson», en R. Brandom, Malden,Mass: Blackwell Publishers, 2000b, pp. 74-80.

(2013), 32(3), Universidad de Oviedo, ISSN: 0210-1602.

UNWIN, N. 2007: Palgrave MacMillan.

WHITING, D., «Should I Believe the Truth?», (2) (2010), pp. 213-224.

- - - «Truth: the Aim and Norm of Belief», Teorema: Revista internacional de filosofía, 32(3) (2013a), pp. 121-135.

- - - «Nothing but the Truth: On the Norms and Aims of Belief», in Chan, T., The Aim of Belief. Oxford: Oxford University Press, 2013b, pp. 184-203.

- - - , «Reasons for Belief, Reasons for Action, the Aim of Belief, and the Aim of Action». Epistemic Norms. Oxford: Oxford University Press, 2014.

Marco Antonio Joven Romero es profesor en el Departamento de Lenguas Extranjeras de la Universidad de Santo Tomás de Manila y lector en la Agencia Española de Cooperación Internacional y Desarrollo (AECID) en Filipinas. Previamente desarrolló su tesis doctoral en el Departamento de Lógica, Historia y Filosofía de la Ciencia de la UNED bajo la dirección del profesor Jesús Zamora Bonilla, gracias a una beca de Formación de Personal Investigador del Gobierno de Aragón y a los proyectos FFI:2013-23267 y FFI:2014-57258-P del Ministerio de Industria, Economía y Competitividad. 
Líneas de investigación:

Epismetología, filosofía de las ciencias sociales, normatividad, filosofía del lenguaje, lingüística comparada, filología aragonesa.

Publicaciones recientes:

- (forthcoming). On the Nature of Belief in Pluralistic Ignorance. Contemporary Pragmatism. University at Buffalo.

- (2017). Unas cuantas cosas sobre la normativización del aragonés. Revista de Filología Románica, 32 (2). Universidad Complutense de Madrid, 325-344.

- (2017). Revolución crítica: aproximación a los cambios sociales actuales como consecuencia del desarrollo y la evolución de las nuevas tecnologías. Anales de la Fundación Joaquín Costa, 29. Instituto de Estudios Altoaragoneses-Diputación Provincial de Huesca.

- (2016). On Norms. An Application of Brennan's and Bicchieri’s Ideas to Bad Citizenship and Civil Disobedience. Saint Louis University Public Law Review: Does Democracty Translate Across Borders?

- (2015). Norms: Between a Social and an Agential Nature. Análisis. Revista de investigación filosófica, 2 (1). Universidad de Zaragoza.

Correo electrónico: majovenromero@gmail.com 
